\title{
Effect of ocean acidification on the structure and fatty acid composition of a natural plankton community in the Baltic Sea
}

\author{
Rafael Bermúdez $^{1,2}$, Monika Winder ${ }^{3}$, Annegret Stuhr ${ }^{1}$, Anna-Karin Almén ${ }^{4}$, Jonna Engström-Öst ${ }^{4,5}$, and \\ Ulf Riebesell ${ }^{1}$ \\ ${ }^{1}$ GEOMAR Helmholtz Centre for Ocean Research Kiel, Kiel, Germany \\ ${ }^{2}$ Facultad de Ingeniería Marítima, Ciencias Biológicas, Oceánicas y Recursos Naturales, Escuela Superior \\ Politécnica del Litoral, ESPOL, Guayaquil, Ecuador \\ ${ }^{3}$ Department of Ecology, Environment and Plant Sciences, Stockholm University, Stockholm, Sweden \\ ${ }^{4}$ Novia University of Applied Sciences, Coastal Zone Research Team, Ekenäs, Finland \\ ${ }^{5}$ Tvärminne Zoological Station, University of Helsinki, J.A. Palménin tie 260, 10900 Hanko, Finland \\ Correspondence to: Rafael Bermúdez (jrbermud@espol.edu.ec)
}

Received: 31 December 2015 - Published in Biogeosciences Discuss.: 18 January 2016

Revised: 15 October 2016 - Accepted: 27 October 2016 - Published: 16 December 2016

\begin{abstract}
Increasing atmospheric carbon dioxide $\left(\mathrm{CO}_{2}\right)$ is changing seawater chemistry towards reduced $\mathrm{pH}$, which affects various properties of marine organisms. Coastal and brackish water communities are expected to be less affected by ocean acidification (OA) as these communities are typically adapted to high fluctuations in $\mathrm{CO}_{2}$ and $\mathrm{pH}$. Here we investigate the response of a coastal brackish water plankton community to increasing $\mathrm{CO}_{2}$ levels as projected for the coming decades and the end of this century in terms of community and biochemical fatty acid (FA) composition. A Baltic Sea plankton community was enclosed in a set of offshore mesocosms and subjected to a $\mathrm{CO}_{2}$ gradient ranging from natural concentrations ( $\left.\sim 347 \mu \mathrm{atm} f \mathrm{CO}_{2}\right)$ up to values projected for the year $2100\left(\sim 1333 \mu\right.$ atm $\left.f \mathrm{CO}_{2}\right)$. We show that the phytoplankton community composition was resilient to $\mathrm{CO}_{2}$ and did not diverge between the treatments. Seston FA composition was influenced by community composition, which in turn was driven by silicate and phosphate limitation in the mesocosms and showed no difference between the $\mathrm{CO}_{2}$ treatments. These results suggest that $\mathrm{CO}_{2}$ effects are dampened in coastal communities that already experience high natural fluctuations in $p \mathrm{CO}_{2}$. Although this coastal plankton community was tolerant of high $p \mathrm{CO}_{2}$ levels, hypoxia and $\mathrm{CO}_{2}$ uptake by the sea can aggravate acidification and may lead to $\mathrm{pH}$ changes outside the currently experienced range for coastal organisms.
\end{abstract}

\section{Introduction}

The steady increase of carbon dioxide $\left(\mathrm{CO}_{2}\right)$ due to anthropogenic emission since the beginning of the industrial era has increased the atmospheric concentration (Boyd et al., 2014). The ocean has a large carbon sink capacity, and increasing atmospheric $\mathrm{CO}_{2}$ absorbed by the ocean is changing the chemistry of the seawater, causing a decline in $\mathrm{pH}$, termed "ocean acidification" (OA; Boyd et al., 2014). OA has been shown to affect various biological processes of diverse marine species (Doney et al., 2009; Kroeker et al., 2010). For instance, OA can impact the biochemical and elemental composition of organisms (Sato et al., 2003; Torstensson et al., 2013), which can be transferred to higher trophic levels (Rossoll et al., 2012). OA can also drive alterations in the community composition structure of primary producers (Hare et al., 2007; Biswas et al., 2011; Schulz et al., 2013). Strong $\mathrm{CO}_{2}$ effects may be particularly significant in marine species that experience low natural fluctuations in $\mathrm{CO}_{2}$ (Riebesell, 2004). In contrast, coastal and brackish-water environments encounter wide and frequent fluctuations in $p \mathrm{CO}_{2}$ (Hinga, 2002; Rossoll et al., 2013) due to large fluxes of organic and inorganic carbon from river run-off (Hinga, 2002), seasonal processes (Melzner et al., 2013) and upwelling of $\mathrm{CO}_{2}-$ enriched water (Feely et al., 2008), all of which lead to wider $\mathrm{pH}$ variation in coastal systems compared to the open ocean (Hinga, 2002). Consequently, it can be expected that coastal 
and brackish communities are more tolerant of OA effects (Rossoll et al., 2013; Reusch and Boyd, 2013), and adverse $\mathrm{CO}_{2}$ effects in terms of the biochemical composition of primary producers and variations in community composition may be diminished.

Fatty acids (FAs) are the main components of lipids in cell membranes. In particular, polyunsaturated fatty acids (PUFAs) have important physiological roles in algae, which synthesise them in high amounts. Heterotrophs at higher trophic levels cannot synthesise certain FAs de novo, especially PUFAs, and have to acquire them from dietary sources (Izquierdo et al., 2001). Diverse laboratory studies of monocultures showed that $\mathrm{CO}_{2}$ alters the FA profile of individual algal species (Sato et al., 2003; Fiorini et al., 2010; Torstensson et al., 2013; Bermúdez et al., 2015). A $\mathrm{CO}_{2}$ driven change in algal food quality can be detrimental for grazers, as has been shown in a laboratory study under elevated $\mathrm{CO}_{2}$ levels (Rossoll et al., 2012). A strong decline of PUFAs in a diatom, grown at high $\mathrm{CO}_{2}$, affected the FA composition of copepods grazing on them and severely impaired their development and egg production rates. Furthermore, increasing seawater $\mathrm{CO}_{2}$ can modify phytoplankton community composition by favouring certain taxa of primary producers (Graeme et al., 2005). In particular, small-sized cells benefit from high $\mathrm{CO}_{2}$ (Hare et al., 2007; Biswas et al., 2011; Brussaard et al., 2013). This is ecologically relevant as taxonomic phytoplankton groups have contrasting FA profiles (Galloway and Winder, 2015) and a change in community structure can affect higher trophic levels. For instance, a field study of two cladocerans with different phytoplankton compositions as food sources showed decreased egg production, lipid reserves, body size and abundance when fed with algae from an acidic lake (Locke and Sprules, 2000).

The above observations suggest that changes in planktonic biochemical make-up and associated shifts in community composition of primary producers as a result of OA can affect the transfer of essential compounds to upper trophic levels. Laboratory studies have shown that algae subjected to longterm high $\mathrm{CO}_{2}$ levels can restore their physiological optima through adaptive evolution (Lohbeck et al., 2012; Bermúdez et al., 2015) and that coastal communities are resilient to OA-driven changes in community composition and biomass (Nielsen et al., 2010; Rossoll et al., 2013). Therefore, it can be expected that organisms in these areas are adapted to high $\mathrm{CO}_{2}$ fluctuations (Thomsen et al., 2010; Nielsen et al., 2010; Rossoll et al., 2013), hampering any $\mathrm{CO}_{2}$-driven effects previously observed in plankton communities (Locke and Sprules, 2000; Biswas et al., 2011).

The goal of the present study was to determine whether an increase in $\mathrm{CO}_{2}$ affects phytoplankton community composition and their FA profile and if any effects are transferred to grazers of a natural plankton community in a coastal/brackish environment. A set of offshore mesocosms, which enclosed a natural plankton assemblage of the Baltic Sea, were used as experimental units. The $\mathrm{CO}_{2}$ levels ranged from current to projected next century values (Boyd et al., 2014, scenario A2). Algal FAs were measured from total seston and from the copepods Acartia bifilosa and Eurytemora affinis, which were the dominant zooplankton during the experiment (Almén et al., 2016).

\section{Material and methods}

\subsection{Experimental set-up and $\mathrm{CO}_{2}$ manipulation}

Our study was conducted during an offshore $\mathrm{CO}_{2}$ mesocosm perturbation experiment off the Tvärminne Zoological Station at the entrance to the Gulf of Finland at $59^{\circ} 51.5^{\prime} \mathrm{N}$, $23^{\circ} 15.5^{\prime} \mathrm{E}$ during late spring 2012 . We used six enclosures with a length of $17 \mathrm{~m}$ containing $\sim 55 \mathrm{~m}^{3}$ of natural sea water (Paul et al., 2015). The mesocosms were set up and manipulated as described in detail by Paul et al. (2015) and Riebesell et al. (2013). Carbon dioxide enrichment was achieved in two phases through the addition of $\mathrm{CO}_{2}$-saturated seawater to four out of six mesocosms. In phase $1, \mathrm{CO}_{2}$ was added in five steps between day 1 and day 5 to achieve values from ambient levels $(\sim 240 \mu \mathrm{atm})$ and a fugacity of carbon dioxide $\left(f \mathrm{CO}_{2}\right)$ up to $\sim 1650$ micro-atmospheres ( $\left.\mu \mathrm{atm}\right)$. In phase 2 on day $15, \mathrm{CO}_{2}$ was again added in the upper $7 \mathrm{~m}$ to compensate for pronounced outgassing in the $\mathrm{CO}_{2}$-enriched mesocosms. As described by Paul et al. (2015), dissolved inorganic carbon and total $\mathrm{pH}$ (on the total $\mathrm{pH}$ scale) were taken every sampling day to determine the carbonate system and determine $f \mathrm{CO}_{2}$ in the mesocosms. Samples for nutrients were collected and analysed as described by Paul et al. (2015). Samples for phytoplankton counts were taken every second day and for fatty acid concentrations every fourth day using a depth-integrated water sampler (Hydrobios, Kiel, Germany), which covered the upper $15 \mathrm{~m}$ of the water column. Integrated zooplankton net tows were taken every seventh day as described by Almén et al. (2016).

\subsection{Phytoplankton abundance and biomass calculation}

Phytoplankton cell counts up to a cell size of $200 \mu \mathrm{m}$ were carried out from $50 \mathrm{~mL}$ water samples, fixed with alkaline Lugol's iodine ( $1 \%$ final concentration) using the Utermöhl's (1958) method with an inverted microscope (ZEISS Axiovert 100). At $200 \times$ magnification, cells larger than $12 \mu \mathrm{m}$ were counted across half of the chamber area, while smaller cells were counted at $400 \times$ magnification on two radial strips. The plankton was identified to genus or species level according to Tomas (1997); Hoppenrath et al. (2009) and Kraberg et al. (2010). Algal biovolume was calculated according to geometric shapes and converted to cellular organic carbon using taxon-specific conversion equations for phytoplankton (Menden-Deuer and Lessard, 2000). 


\subsection{Fatty acid composition}

For analysis of seston fatty acid (FA), $500 \mathrm{~mL}$ of seawater was filtered by a $100 \mu \mathrm{m}$ size pore net and samples were collected in a pre-combusted $\left(450^{\circ} \mathrm{C}, 6 \mathrm{~h}\right)$ Whatman $\mathrm{GF} / \mathrm{F}$ $(\sim 0.7 \mu \mathrm{m}$ nominal pore size) filters. For zooplankton, gravid copepod females of Acartia bifilosa and Eurytemora affinis were picked up with sterile tweezers under two stereomicroscopes (Nikon SMZ800, 25× magnification and Leica $25 \times$ magnification) and placed in pre-weighted tin cups. All samples were immediately stored at $-80^{\circ} \mathrm{C}$ until analysis. FAs were measured by gas chromatography as fatty acid methyl esters (FAMEs) following Breteler et al. (1999). Lipids were extracted overnight from the filters using $3 \mathrm{~mL}$ of a solvent mixture (dichloromethane: methanol: chloroform in $1: 1: 1$ volume ratios). As an internal standard, FAME C19:0 (Restek, Bad Homburg, Germany; $c=20$ ng of component per sample) was added, and a C23:0 FA standard $\left(c=25.1 \mathrm{ng}_{\mu \mathrm{L}}^{-1}\right)$ was used as an esterification efficiency control (usually $80-85 \%$ ). Water-soluble fractions were removed by washing the samples with $2.25 \mathrm{~mL}$ of $\mathrm{KCl}$ solution $\left(c=1 \mathrm{~mol} \mathrm{~L}^{-1}\right)$, and the remainder dried by addition of $\mathrm{NaSO}_{4}$. The solvent was evaporated to dryness in a rotary film evaporator (100-150 mbar), redissolved in chloroform and transferred into a glass cocoon. The solvent was evaporated again (10-30 mbar), and esterification was performed overnight using $200 \mu \mathrm{L} 1 \% \mathrm{H}_{2} \mathrm{SO}_{4}$ (in $\mathrm{CH}_{3} \mathrm{OH}$ ) and $100 \mu \mathrm{L}$ toluene at $50^{\circ} \mathrm{C}$. Phases were split using $300 \mu \mathrm{L} 5 \%$ sodium chloride solution, and FAMEs were separated using n-Hexane, transferred into a new cocoon, evaporated and $100 \mu \mathrm{L}$ (final volume) was added. All solvents used were gas chromatography (GC) grade. FAMEs were analysed using a Thermo GC Ultra gas chromatograph equipped with a non-polar column (RXI1-SIL-MS $0.32 \mu \mathrm{m}, 30 \mathrm{~m}$, company Restek) and Flame ionisation detector. The column oven was initially set to 100 and heated to $220^{\circ} \mathrm{C}$ at $2{ }^{\circ} \mathrm{C} \mathrm{min}^{-1}$. The carrier gas was helium at a constant flow of $2 \mathrm{~mL} \mathrm{~min}^{-1}$. The flame ionisation detector was set to $280^{\circ} \mathrm{C}$, with gas flows of 350,35 and $30 \mathrm{~mL} \mathrm{~min}^{-1}$ for synthetic air, hydrogen and helium respectively. A $1 \mu \mathrm{L}$ aliquot of the sample was injected. The system was calibrated with a 37-component FAME-mix (Supelco, Germany) and chromatograms were analysed using Chrom-Card Trace-Focus GC software and the fatty acids were clustered according to their degree of saturation: saturated (SFA), monounsaturated (MUFA) and polyunsaturated (PUFA).

\subsection{Statistical analyses}

The data were analysed with a nested mixed-effects ANOVA model (LME) to determine the differences in taxa biomass $\left(\mu \mathrm{gC} \mathrm{mL}{ }^{-1}\right)$ and relative fatty acid content $(\%$ in the seston and zooplankton) between the $\mathrm{CO}_{2}$ treatments ( $\mu$ atm $f \mathrm{CO}_{2}$ ), with $f \mathrm{CO} 2$, silicate, inorganic nitrogen (nitrite + nitrate), phosphate, temperature and salinity as fixed effects and sam-

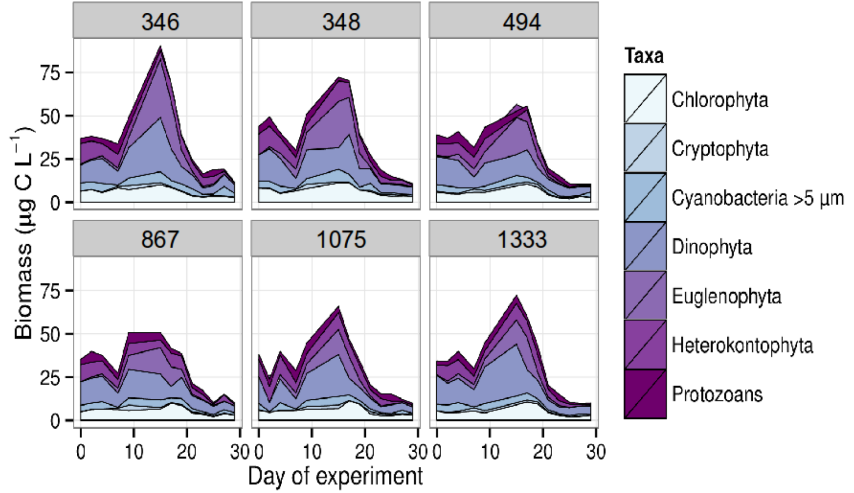

Figure 1. Calculated biomass after cell counts of the main plankton taxonomic groups in the different $\mathrm{CO}_{2}$ treatments between days 1 and 29. Each treatment is labelled with the average $f \mathrm{CO}_{2}$ level of the entire experimental period (top).

pling day and mesocosm position as nested random variables (random distribution of $\mathrm{CO}_{2}$ treatments among the mesocosm). Average mesocosm $f \mathrm{CO}_{2}$ was calculated for the total duration of the sampling period plankton community composition (days 1 to 29) and for FA data analysis (days 1 to 25 for seston FA and days -1 to 33 for zooplankton FA). Linear regression models were used to determine the relation between PUFA and phytoplankton biomass. The similarity in the structure of the plankton community between the treatments was analysed using non-metric multidimensional scaling (NMDS) with Bray distance, auto-transformation and 3 dimensions $(k=3)$. This analysis distributes the samples in an ordination space according to the biomass of the different taxa in the community along orthogonal principal components using non-Euclidean distances for ordination space, which makes it more robust to the presence of zero values (Clarke, 1993). All statistical analyses were done using the R software environment 3.0.1 (R Development Core Team, 2013).

\section{Results}

\subsection{Plankton community composition}

The initial algal community consisted of post-bloom species dominated by small-sized cells, with dinophyta being the most abundant phytoplankton group in all mesocosm throughout the experiment followed by heterokontophyta, euglenophyta, cholorophyta, cyanobacteria bigger than $5 \mu \mathrm{m}$ (usually filamentous) and small abundances of cryptophyta (Fig. 1). Microzooplankton was present during the entire experimental period, particularly the choanoflagellate Calliacantha natans (Fig. 1). The plankton community was analysed from days 1 to 29, which comprised of two phases as described by Paul et al. (2015). In phase 1 (from days 1 to 15), phytoplankton biomass gradually increased until day 10 
(a)
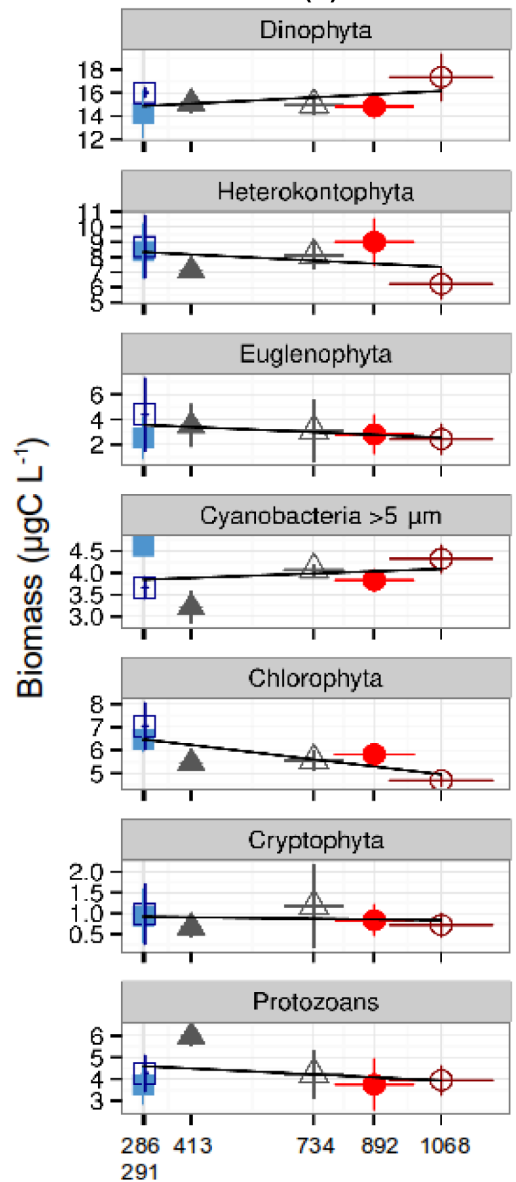

(b)
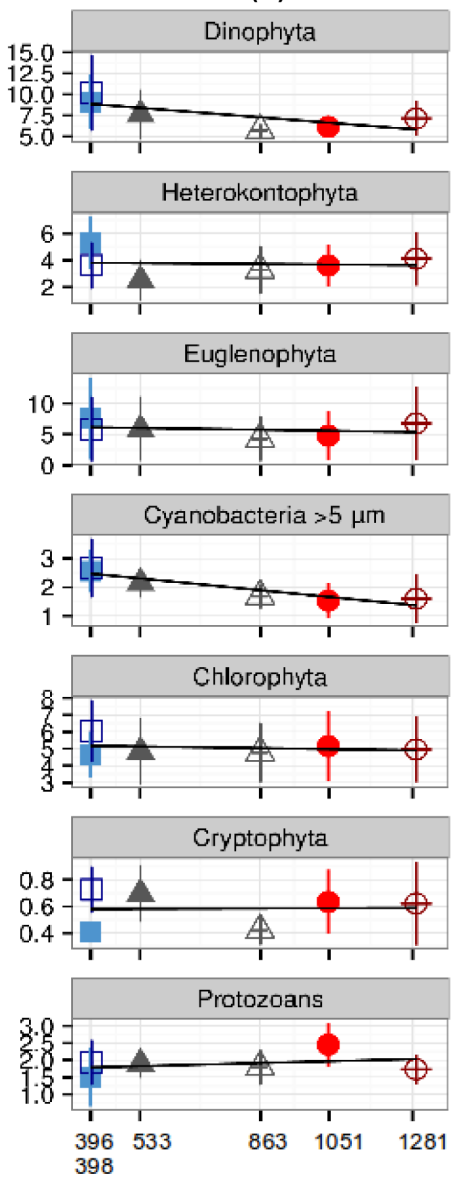

(d)

(
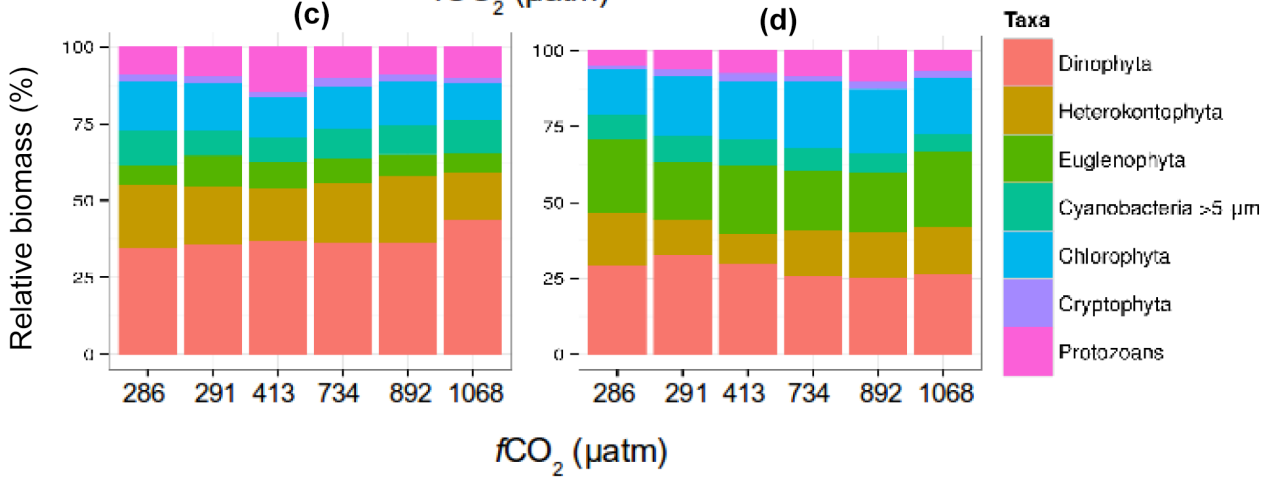

Figure 2. The top panels show the mean of the calculated biomass of each plankton taxon in (a) phase 1, between days 0 and 15 and (b) phase 2, between days 15 and 29, in the $\mathrm{CO}_{2}$ gradient treatments. The bottom panels show the relative biomass of the different plankton groups between (c) phases 1 and (d) phase 2. The $x$ axes show the measured average $f \mathrm{CO}_{2}$ in each phase, error bars show standard error in (a) and (b) $(n=5$ for $\mathbf{a} ; n=5$ for $\mathbf{b})$.

when a bloom started and it reached a peak around day 15 in all treatments, while in phase 2 (from days 17 to 29) the biomass began to decay from around day 19 up to day 29 (Fig. 1).

The more abundant taxa did not show differences in abundance between the $\mathrm{CO}_{2}$ treatments on both phases (Fig. 2a, b). However, the biomass of some of the less abundant groups was affected by $\mathrm{CO}_{2}$ within the different phases. In phase 1 , the nested mixed effects model analysis of the algal biomass showed that chlorophyta decrease significantly towards high $\mathrm{CO}_{2}$ levels (Fig. 2a; LME, $F=7.27, p=0.01, \mathrm{~d} f=20)$. Nevertheless, there was a difference in the relative biomass of the more abundant plankton groups between phases 1 and 2, with a decrease in 
dinophyta (37.2 \pm 3.2 to $28.3 \pm 2.9 \%)$ and heterokontophyta $(19.1 \pm 2.2 \%$ to $14 \pm 2.6)$ from phase 1 (Fig. $2 \mathrm{c})$ to phase 2 (Fig. 2d), and an increase of euglenophyta $(7.5 \pm 1.4 \%$ to $21 \pm 2.7)$ and chlorophyta $(14.0 \pm 1.5 \%$ to $19.1 \pm 2.4)$ in the same period. An NMDS analysis of the entire phytoplankton community showed a rather homogeneous community composition between the different $\mathrm{CO}_{2}$ treatments but variation among sampling days, especially on day 7, when the diatom Melosira varians was abundant during that particular sampling day (Fig. S1 in the Supplement).

\subsection{Seston fatty acid composition}

The PUFAs represented on average $\sim 26 \pm 4$, MUFAs $\sim 22 \pm 3$ and SFAs $\sim 52 \pm 4 \%$ of the total FA content in the seston over the entire experimental period. The LME analysis of relative PUFA content data showed no significant difference among the $\mathrm{CO}_{2}$ treatments (LME, $F_{45}=0.0$, $p>0.05$;Fig. 3a PUFA). Neither did the MUFAs and SFAs show any significant change in abundance in relation with $\mathrm{CO}_{2}\left(\mathrm{LME}, F_{45}=0.0, p=0.8\right.$ and $F_{45}=0.06, p=0.79$; Fig. 3a shows MUFA and SFA). However, the FA composition of the seston showed that the relative PUFA content significantly decreased over time in all mesocosms (linear regression, $R^{2}=0.52, t=-7.64, p<0.0001, n=22$; Fig. 3b shows high $\mathrm{CO}_{2}$ treatments and low $\mathrm{CO}_{2}$ treatments), while the MUFA and SFA increased, although the relation of both with time is weak (linear regression, $R^{2}=0.12$, $t=2.88, p=0.005$ and $R^{2}=0.15, t=3.26, p=0.001$, $n=22$; Fig. S2). Regarding specific PUFAs, 18:2n6c showed a significant correlation with $\mathrm{CO}_{2}$ and $\mathrm{Si}, 16: 3 \mathrm{n} 4$ with $\mathrm{CO}_{2}$, $\mathrm{P}$ and $\mathrm{Si}$ and 18:3n6 with $\mathrm{CO}_{2}$ and $\mathrm{N}$ (Fig. S3).

Nevertheless, PUFAs showed a positive relation with heterokontophyta (linear regression, $R^{2}=0.58, p<0.001$ ) and dinophyta (linear regression, $R^{2}=0.41, p<0.001$ ) biomass (Fig. 4a), and with an abundance of silicate (LME, $F=22.8$, $p<0.001, \mathrm{~d} f=35$ ) and phosphate (LME, $F=9.3, p<0.01$, $\mathrm{d} f=35$ ) in the mesocosms (Fig. 4b). The PUFAs 18:2n6c and $18: 3 n 3$ showed a positive effect of silicate, while $20: 5 \mathrm{n} 3 \mathrm{c}$ and $22: 6 n 3 c$ showed a significant effect of silicate and phosphate (Fig. S4).

\subsection{Copepod fatty acids}

The overall PUFA content represented $\sim 12 \%(311 \pm 175 \mathrm{ng}$ FA mg dry $\mathrm{wt}^{-1}$ ) of the total FA of the copepod A. bifilosa and in E. affinis it was $\sim 16 \%(433 \pm 597 \mathrm{ng}$ FA mg dry $\left.\mathrm{wt}^{-1}\right)$.

The FAs did not show a $\mathrm{CO}_{2}$-related effect in $A$. bifilosa (LME, $F=0.62, p=0.4374, \mathrm{~d} f=26$; Fig. 5a) or E. affinis $(F=0.13, p=0.71, \mathrm{~d} f=26$; Fig. 5b). Nevertheless, the relative PUFA content of A. bifilosa and E. affinis showed a significant decrease over time in all high and low $\mathrm{CO}_{2}$ treatments (linear regression, A. bifilosa; $R^{2}=0.22$, $t=-3.288, p=0.002$ E. affinis; $R^{2}=0.47, t=-5.51$, (a)
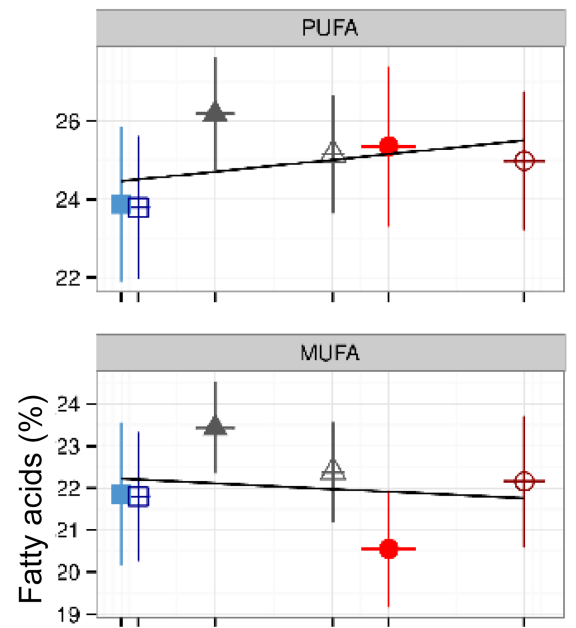
$\mathrm{fCO}_{2}$ ( $\left.\mu \mathrm{atm}\right)$

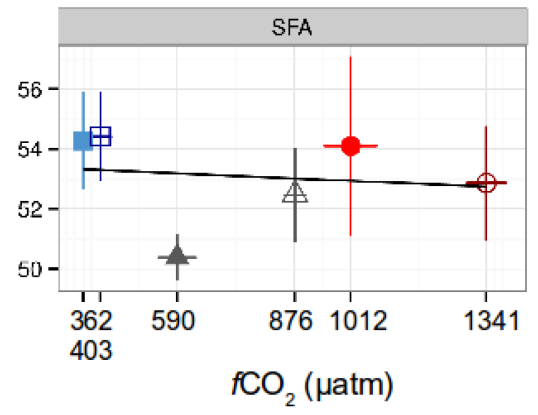

362

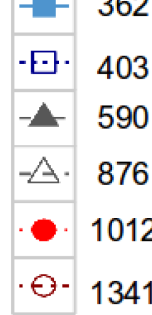

(b)

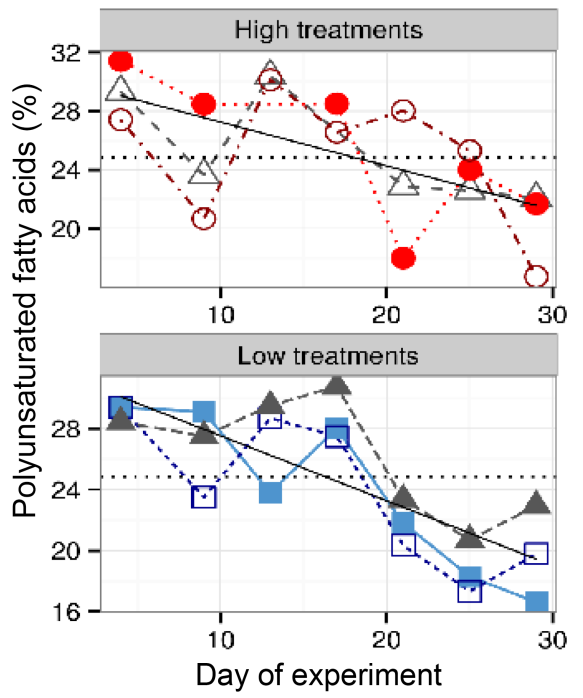

Figure 3. (a) Relative polyunsaturated (PUFAs), monounsaturated (MUFAs) and saturated (SFAs) fatty acids content in the seston as a function of $f \mathrm{CO}_{2}$ between days 1 and 29. The $x$ axes show the mean $f \mathrm{CO}_{2}$ measured during the sampling period, bars shows standard error. (b) Relative PUFA composition of the seston showed over time in the 876, 1012 and $1314 \mu$ atm $f \mathrm{CO}_{2}$ levels (high $\mathrm{CO}_{2}$ treatments) and the 362,403 and $590 \mu$ atm $f \mathrm{CO}_{2}$ levels (low $\mathrm{CO}_{2}$ treatments). Horizontal dashed line indicates the position of the overall mean PUFA value. 
(a)

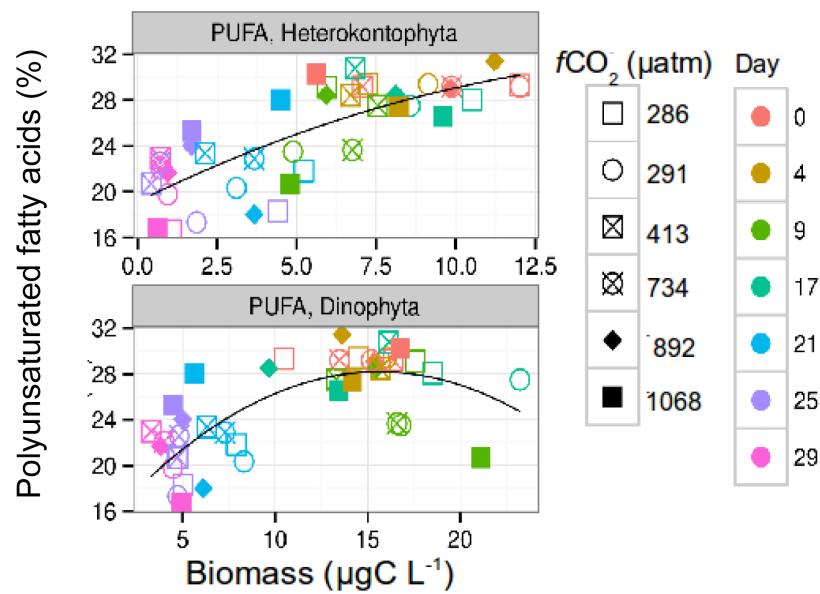

(b)

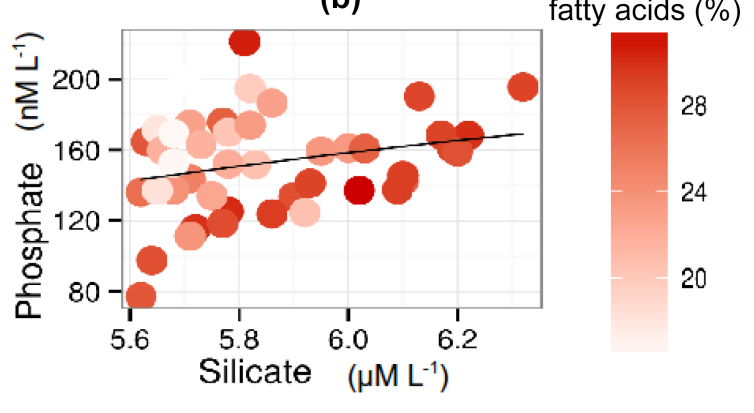

Figure 4. (a) Relation between sestonic relative polyunsaturated fatty acids (PUFAs) with heterokontophyta (PUFA, heterokontophyta) and dinophyta (PUFA, dinophyta) biomass. (b) Relation between relative sestonic PUFA content with silicate and phosphate abundance in the mesocosms.

$p<0.0001$; Fig. 5c) but no specific PUFA in A. bifilosa (Fig. S5) or E. affinis did (Fig. S6). However there was a decrease in MUFA and an increase in SFA in both copepod species (Fig. S7). Furthermore, the relative FA content in $E$. affinis varied over time following the changes in the seston FA. This relation was significant but weak for PUFA, MUFA and SFA (Fig. S8), while in A. bifilosa this change appeared only in MUFA (Fig. S8).

\section{Discussion}

\subsection{Community composition}

The plankton community composition in the present experiment changed over time and showed few differences in relation to the different $\mathrm{CO}_{2}$ treatments. The observed absence of a strong $\mathrm{CO}_{2}$ effect on the community composition in the present study is in line with the observations in the western Baltic Sea (Thomsen et al., 2010; Nielsen et al., 2010; Rossoll et al., 2013). In these studies, the authors suggested that the plankton community is adapted to OA due to the re- current large seasonal and daily variance of $\mathrm{pH}$ and $\mathrm{CO}_{2} \mathrm{ex}-$ perienced by the communities in this productive low-salinity region (Thomsen et al., 2010; Nielsen et al., 2010; Rossoll et al., 2013; Almén et al., 2014). Our study region, a coastal zone in the western Gulf of Finland in the northern Baltic Sea, is a brackish environment with low salinity $(\sim 5.7 \%$ o $)$ and has a high fresh water run-off $\left(\sim 111 \mathrm{~km}^{3} \mathrm{yr}^{-1}\right.$; Savchuk, 2005 ) and a strong inter- and intra-seasonal $\mathrm{pH}$ variability, sometimes reaching extreme values of 9.2 and 7.4 with an average of 8.1 (Brutemark et al., 2011). Therefore, it seems that the plankton community in our study area, which experiences high natural $\mathrm{pH}$ fluctuations, is composed of species and genotypes that are less $\mathrm{pH} / \mathrm{CO}_{2}$ sensitive (Nielsen et al., 2010; Lohbeck et al., 2012; Melzner et al., 2013; Rossoll et al., 2013), which allows them to cope with the $\mathrm{CO}_{2}$ range applied in the current field experiment.

Chlorophytes were the only group that showed a significant response to the $\mathrm{CO}_{2}$ treatment, although their contribution to total biomass was low. Chlorophytes decreased at elevated $f \mathrm{CO}_{2}$, which is in contrast to laboratory studies showing that several species in this group benefit from high $\mathrm{CO}_{2}$ and can increase their growth rates (Tsuzuki et al., 1990; Yang and Gao, 2003).

\subsection{Seston FAs}

The relative PUFA content of seston showed a significant decrease over time, which can be attributed to nutrient depletion in the mesocosms, particularly silicate and phosphate concentrations, which caused a decrease in dinophyta and heterokontophyta abundances. These two groups of microalgae have been identified as rich in PUFA content (Galloway and Winder, 2015) and their decrease in the mesocosms explains the concomitant decrease in PUFA. Silicate is required by heterokontophyta for the formation of new frustules during cell division and, when limited, cell division stops (Flynn, 2000). Phosphorus is required for the production of PUFA-rich membrane phospholipids during cell division and growth (Guschina and Harwood, 2009). Nutrient limitation, which causes reduced cell division rates, results in a lower production of phospholipid and increased production of storage lipid, primarily triacylglycerols (Guschina and Harwood, 2009). Triacylglycerols are rich in SFA and MUFA; therefore the increase in triacylglycerols with nutrient limitation typically resulted in decreased proportions of PUFA in most algae (Guschina and Harwood, 2009). This is consistent with our observations in the mesocosms, where the relative PUFA content of seston followed the phosphate concentration. From this perspective, one may expect that any $\mathrm{CO}_{2}$ effect in algal PUFA will occur when cells are actively growing, since nutrient limitation (silicate and phosphorus) will have more profound consequences in the physiology of the cell than an excess of $\mathrm{CO}_{2}$.

The absence of a PUFA response to $\mathrm{CO}_{2}$ is countered by a report of an Arctic plankton community showing an increase 
(a)
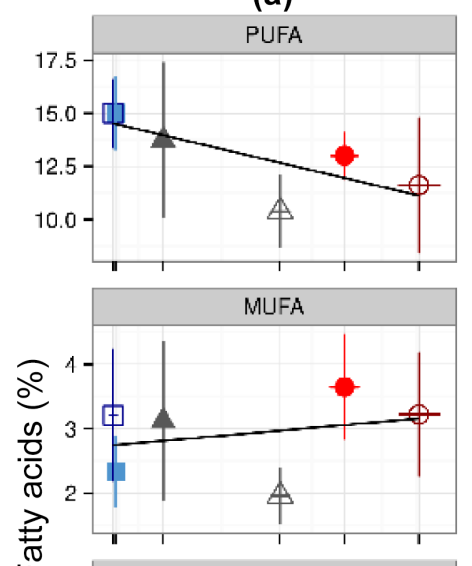

एँ

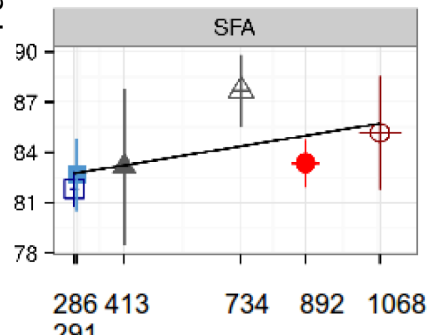

291 (b)
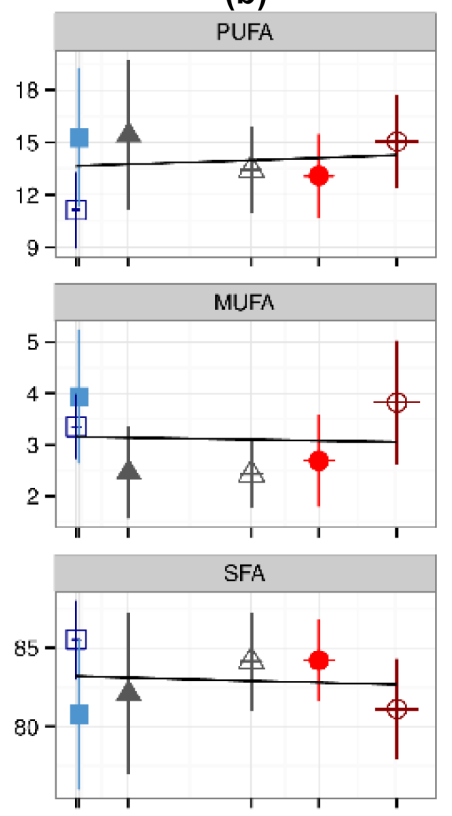

$\begin{array}{lll}734 & 892 & 1068\end{array}$

$\mathrm{fCO}_{2}$ ( $\mu$ atm)

(c)

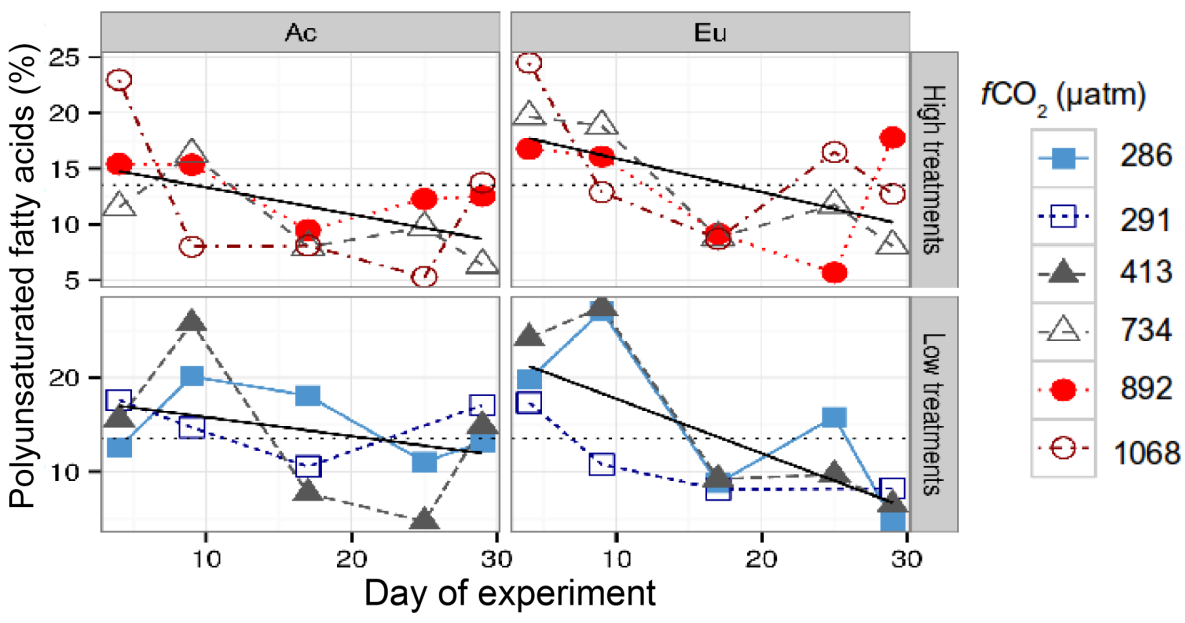

Figure 5. Panels (a) and (b) show the relative polyunsaturated (PUFA), monounsaturated (MUFA) and saturated (SFA) fatty acid content in the copepods Acartia bifilosa and Eurytemora affinis, respectively, under the $f \mathrm{CO}_{2}$ gradient treatments between days 1 and 29 . The $x$ axes show the mean $f \mathrm{CO}_{2}$ measured during the sampling period, bars shows standard error. (c) Relative PUFA composition of Acartia bifilosa (Ac) and Eurytemora affinis (Eu) over time in the 876, 1012 and $1314 \mu$ atm $f \mathrm{CO}_{2}$ levels (high $\mathrm{CO}_{2}$ treatments) and the 362 , 403 and $590 \mu \mathrm{atm} f \mathrm{CO}_{2}$ levels (low $\mathrm{CO}_{2}$ treatments). Horizontal dashed line indicates the position of the overall mean PUFA value.

of PUFA at high $\mathrm{CO}_{2}$ levels during part of a mesocosm experiment experiencing nutrient additions (Leu et al., 2013). This was attributed to a change in the plankton community composition due to a rise in abundance of dinoflagellates at high $\mathrm{CO}_{2}$ (Leu et al., 2013). Our results show a decrease in PUFA due to a decline in dinoflagellates. The different PUFA trends between these experiments can be attributed to the specific plankton community composition and their re- lated FA profiles alongside limited phosphate and silicate in our study, which causes a reduction of the biomass of some PUFA-rich taxa. Species composition of a natural plankton assemblage determines its food quality properties as distinct algal taxonomic groups have different FA composition profiles (Galloway and Winder, 2015). A $\mathrm{CO}_{2}$-driven change in the Arctic plankton community composition (Leu et al., 2013) promoted the presence of species rich in PUFA. In our 
study the absence of a $\mathrm{CO}_{2}$ response in taxa composition and the apparent influence of phosphate and silicate limitation in the algal FA composition resulted in a rather homogeneous PUFA concentration between $\mathrm{CO}_{2}$ treatments.

\subsection{Copepod fatty acids}

Our results showed that the PUFA concentration of the dominating copepod species, $A$. bifilosa and $E$. affinis did not vary between the different $\mathrm{CO}_{2}$ treatments. However, the PUFAs decrease in both copepods over the experimental period reflects the decline in the PUFA content of the seston. This observation is consistent with other studies showing that copepods strongly rely on their diet as a source of FA and that their composition, especially PUFA, mirrors the algae they graze on (Ishida et al., 1998; Caramujo et al., 2007; Rossoll et al., 2012).

Several studies have shown a limited direct effect on $\mathrm{CO}_{2}$ in the copepod FA of some species, like the genus Acartia, which is rather insensitive to projected high $\mathrm{CO}_{2}$ exposure up to $5000 \mu \mathrm{atm} \mathrm{CO}_{2}$ (Kurihara et al., 2004; Kurihara and Ishimatsu, 2008). Copepods experience widely varying $\mathrm{pH}$ conditions on a daily basis during their vertical migration, shown in the same area as the current study (Almén et al., 2014), which may explain their tolerance to $\mathrm{pH}$ variations. Several studies have demonstrated that food quality of the available prey in terms of PUFA content can affect egg production, hatching success and nauplii survival in copepods (Jónasdóttir, 1994; Jónasdóttir et al., 2009; Caramujo et al., 2007). Indirect adverse $\mathrm{CO}_{2}$ effects through the diet of primary consumers have been reported in laboratory and field experiments (Rossoll et al., 2012; Locke and Sprules, 2000). However, the absence of a $\mathrm{CO}_{2}$-driven change in the community composition of primary producers and the homogeneous algal FA composition due to phosphate and silicate limitations masked any noticeable $\mathrm{CO}_{2}$-related effects in the algae FA profile which could have affected the copepods during our experiment.

\section{Conclusions}

Considering that the Baltic Sea is a coastal sea with a natural frequent and wide $\mathrm{pH}$ variability (Omstedt et al., 2009), it can be expected that the effects of OA on plankton communities will be rather small within the range of predicted values for this century (Havenhand, 2012). A reduced OA sensitivity in systems experiencing high $\mathrm{CO}_{2}$ fluctuations is supported by our results and other studies using communities from the Baltic (Thomsen et al., 2010; Nielsen et al., 2010; Rossoll et al., 2013). However, in coastal upwelling areas undergoing an increase in hypoxic events, it is likely that elevated $\mathrm{CO}_{2}$ values presently experienced by coastal organisms and projected by the end of the century (Melzner et al., 2013) will be more recurrent in the future (Feely et al., 2004), with a potential to affect various properties of plankton communities.

Nonetheless, it is clear that the plankton community response to $\mathrm{OA}$ and concomitant effects on its food quality for higher trophic levels will strongly depend on the sensitivity of primary producers and on how OA affects the species composition of plankton assemblages (Leu et al., 2013; Rossoll et al., 2013). This result is important as any change in primary producers in terms of FAs, in particular essential biomolecules such as PUFAs, may scale up in food webs since FAs are incorporated into the lipids of larval fish (Fraser et al., 1989; Izquierdo et al., 2001). Considering that fish is a critical natural resource (FAO, 2010), adverse OA effects on food quality can reach human populations, who rely on fisheries as an important food source (Sargent et al., 1997; Arts et al., 2001).

\section{Data availability}

The phytoplankton biomass and relative fatty acid data can be found in Bermúdez et al. (2016; https://issues.pangaea.de/ browse/PDI-13719)

Most other variables from the experiment (e.g. fugacity of carbon dioxide and nutrients) can be found in Paul et al. (2016; doi:10.1594/PANGAEA.863032).

\section{The Supplement related to this article is available online at doi:10.5194/bg-13-6625-2016-supplement.}

Acknowledgements. We thank the KOSMOS team and all of the participants in the mesocosm campaign for their support during the experiment. In particular, we would like to thank Andrea Ludwig for co-ordinating the campaign logistics and assistance with CTD operations and the diving team. We also gratefully acknowledge the captain and crew of RV ALKOR (AL394 and AL397) for their work transporting, deploying and recovering the mesocosms and the Tvärminne station and staff for their logistic support. This collaborative project was funded by BMBF projects BIOACID II (FKZ 03F06550) and SOPRAN Phase II (FKZ 03F0611).

The article processing charges for this open-access publication were covered by a Research

Centre of the Helmholtz Association.

Edited by: H.-P. Grossart

Reviewed by: three anonymous referees

\section{References}

Almén, A., Vehmaa, A., Brutemark, A., and Engström-öst, J.: Coping with climate change? Copepods experience drastic variations in their physicochemical environment on a 
diurnal basis, J. Exp. Mar. Biol. Ecol., 460, 120-128, doi:10.1016/j.jembe.2014.07.001, 2014.

Almén, A.-K., Vehmaa, A., Brutemark, A., Bach, L., Lischka, S., Stuhr, A., Furuhagen, S., Paul, A., Bermúdez, J. R., Riebesell, U., and Engström-Öst, J.: Negligible effects of ocean acidification on Eurytemora affinis (Copepoda) offspring production, Biogeosciences, 13, 1037-1048, doi:10.5194/bg-13-1037-2016, 2016.

Arts, M. T., Ackman, R. G., and Holub, B. J.: "Essential fatty acids" in aquatic ecosystems: a crucial link between diet and human health and evolution, Can. J. Fish. Aquat. Sci., 58, 122-137, doi:10.1139/f00-224, 2001.

Bermúdez, R., Feng, Y., Roleda, M. Y., Tatters, A. O., Hutchins, D. a., Larsen, T., Boyd, P. W., Hurd, C. L., Riebesell, U., and Winder, M.: Long-term conditioning to elevated $p \mathrm{Co}_{2}$ and warming influences the fatty and amino acid composition of the diatom Cylindrotheca fusiformis, PLoS One, 10, e0123945, doi:10.1371/journal.pone.0123945, 2015.

Biswas, H., Cros, A., Yadav, K., Ramana, V. V., Prasad, V. R., Acharyya, T., and Babu, P. V. R.: The response of a natural phytoplankton community from the Godavari River Estuary to increasing $\mathrm{CO}_{2}$ concentration during the premonsoon period, J. Exp. Mar. Biol. Ecol., 407, 284-293, doi:10.1016/j.jembe.2011.06.027, 2011.

Boyd, P. W., Cheung, W., Lluch-Cota, S. E., Nojiri, Y., Schmidt, D., and Zavialov, P.: Climate Change 2013: The physical science basis. Contribution of working group II to the fifth assessment report of the intergovernmental panel on climate change, Cambridge University Press, Cambridge, United Kingdom and New York, NY, USA, 1535 pp., doi:10.1017/CBO9781107415324, 2014

Breteler, W., Schogt, N., and Baas, M.: Trophic upgrading of food quality by protozoans enhancing copepod growth: role of essential lipids, Mar. Biol., 135, 191-198, doi:10.1007/s002270050616, 1999.

Brussaard, C. P. D., Noordeloos, A. A. M., Witte, H., Collenteur, M. C. J., Schulz, K., Ludwig, A., and Riebesell, U.: Arctic microbial community dynamics influenced by elevated $\mathrm{CO}_{2}$ levels, Biogeosciences, 10, 719-731, doi:10.5194/bg-10-719-2013, 2013.

Brutemark, A., Engström-Öst, J., and Vehmaa, A.: Long-term monitoring data reveal $\mathrm{pH}$ dynamics, trends and variability in the western Gulf of Finland, Oceanol. Hydrobiol. Stud., 40, 91-94, doi:10.2478/s13545-011-0034-3, 2011.

Caramujo, M.-J., Boschker, H. T. S., and Admiraal, W.: Fatty acid profiles of algae mark the development and composition of harpacticoid copepods, Freshw. Biol., 53, 77-90, doi:10.1111/j.1365-2427.2007.01868.x, 2007.

Clarke, K.: Non-parametric multivariate analyses of changes in community structure, Aust. J. Ecol., 18, 117-143, doi:10.1111/j.1442-9993.1993.tb00438.x, 1993.

Doney, S. C., Fabry, V. J., Feely, R. A., and Kleypas, J. a.: Ocean Acidification: The other $\mathrm{CO}_{2}$ problem, Annu. Rev. Mar. Sci., 1, 169-192, doi:10.1146/annurev.marine.010908.163834, 2009.

Feely, R. A., Sabine, C. L., Lee, K., Berelson, W., Kleypas, J., Fabry, V. J., and Millero, F. J.: Impact of anthropogenic $\mathrm{CO}_{2}$ on the $\mathrm{CaCO}_{3}$ system in the oceans, Science, 305, 362-366, doi:10.1126/science.1097329, 2004.

Feely, R., Sabine, C., Hernandez-Ayon, J., Ianson, D., Hales, B.: Evidence for upwelling of corrosive "acidified" ater onto the continental shelf, Science, 320, 1490-1492, doi:10.1126/science.1155676, 2008.

Fiorini, S., Gattuso, J.-P., van Rijswijk, P., and Middelburg, J.: Coccolithophores lipid and carbon isotope composition and their variability related to changes in seawater carbonate chemistry, J. Exp. Mar. Biol. Ecol., 394, 74-85, doi:10.1016/j.jembe.2010.07.020, 2010.

Flynn, K. J.: Modelling Si-N-limited growth of diatoms, J. Plankton Res., 22, 447-472, doi:10.1093/plankt/22.3.447, 2000.

FAO: Food And Agriculture Organization Of The United Nations: The State of World Fisheries and Aquaculture 2010, edited by: de Séligny, J. and Grainger, R., Rome, ISBN 978-92-5-1066751,2010

Fraser, A. J., Sargent, J. R., and Gamble, J. C.: Lipid class and fatty acid composition of Calanus finmarchicus (Gunnerus), Pseudocalanus sp. and Temora longicornis Muller from a nutrientenriched seawater enclosure, J. Exp. Mar. Biol. Ecol., 130, 8192, doi:10.1016/0022-0981(89)90020-8, 1989.

Galloway, A. W. E. and Winder, M.: Partitioning the relative importance of phylogeny and environmental conditions on phytoplankton fatty acids, PLoS One, 10, e0130053, doi:10.1371/journal.pone.0130053, 2015.

Graeme, H. C., Richardson, A. J., and Robinson, C.: Climate change and marine plankton, Trends Ecol. Evol., 20, 337-44, doi:10.1016/j.tree.2005.03.004, 2005.

Guschina, I. A. and Harwood, J. L.: Algal lipids and effect of the environment on their biochemistry, in: Lipids in aquatic ecosystems, edited by: Arts, M. T., Brett, M. T., and Kainz, M., Springer, New York, USA, Lipids, 1-24, doi:10.1007/978-0-38789366-2_1, 2009.

Hare, C., Leblanc, K., DiTullio, G., Kudela, R., Zhang, Y., Lee, P., Riseman, S., and Hutchins, D.: Consequences of increased temperature and $\mathrm{CO}_{2}$ for phytoplankton community structure in the Bering Sea, Mar. Ecol.-Prog. Ser., 352, 9-16, doi:10.3354/meps07182, 2007.

Havenhand, J. N.: How will ocean acidification affect Baltic sea ecosystems? An assessment of plausible impacts on key functional groups, Ambio, 41, 637-44, doi:10.1007/s13280-0120326-x, 2012.

Hinga, K.: Effects of $\mathrm{pH}$ on coastal marine phytoplankton, Mar. Ecol.-Prog. Ser., 238, 281-300, doi:10.3354/meps238281, 2002.

Hoppenrath, M., Elbrächter, M., Drebes, G., and Marine Phytoplankton: Selected microphytoplankton species from the North Sea around Helgoland and Sylt, E. Schweizerbart'sche Verlagsbuchhandlung, Stuttgart, Germany, ISBN 978-3-510-61392-2, 264 pp., 2009.

Ishida, Y., Yokoi, H., Isomura, S., Ohtani, H., Tsuge, S., Sekino, T., Nakanishi, M., and Kimoto, T.: Correlation analysis between fatty acid compositions of zooplankter individuals, fed on different phytoplankton species by means of pyrolysis-gas chromatography combined with on-line methylation, J. Chromatogr. B. Biomed. Sci. Appl., 716, 39-45, doi:10.1016/S03784347(98)00318-1, 1998.

Izquierdo, M., Fernández-Palacios, H., and Tacon, A. G.: Effect of broodstock nutrition on reproductive performance of fish, Aquaculture, 197, 25-42, doi:10.1016/S0044-8486(01)00581-6, 2001.

Jónasdóttir, S., Visser, A., and Jespersen, C.: Assessing the role of food quality in the production and hatching of 
Temora longicornis eggs, Mar. Ecol.-Prog. Ser., 382, 139-150, doi:10.3354/meps07985, 2009.

Jónasdóttir, S. H.: Effects of food quality on the reproductive success of Acartia tonsa and Acartia hudsonica: laboratory observations, Mar. Biol., 121, 67-81, doi:10.1007/BF00349475, 1994.

Kraberg, A., Baumann, M., Dürselen, C.-D., and Coastal Phytoplankton: Photo Guide for Northern European Seas, Verlag Dr. Friedrich Pfeil, Munchen, Germany, ISBN 978-3-89937-113-0, 204 pp., 2010.

Kroeker, K. J., Kordas, R. L., Crim, R. N., and Singh, G. G.: Meta-analysis reveals negative yet variable effects of ocean acidification on marine organisms, Ecol. Lett., 13, 1419-1434, doi:10.1111/j.1461-0248.2010.01518.x, 2010.

Kurihara, H. and Ishimatsu, A.: Effects of high $\mathrm{CO}_{2}$ seawater on the copepod Acartia tsuensis through all life stages and subsequent generations, Mar. Pollut. Bull., 56, 1086-1090, doi:10.1016/j.marpolbul.2008.03.023, 2008.

Kurihara, H., Shimode, S., and Shirayama, Y.: Sub-lethal effects of elevated concentration of $\mathrm{CO}_{2}$ on planktonic copepods and sea urchins, J. Oceanogr., 60, 743-750, doi:10.1007/s10872-0045766-x, 2004.

Leu, E., Daase, M., Schulz, K. G., Stuhr, A., and Riebesell, U.: Effect of ocean acidification on the fatty acid composition of a natural plankton community, Biogeosciences, 10, 1143-1153, doi:10.5194/bg-10-1143-2013, 2013.

Locke, A. and Sprules, W. G.: Effects of acidic $\mathrm{pH}$ and phytoplankton on survival and condition of Bosmina longirostris and Daphnia pulex, Hydrobiologia, 187-196, doi:10.1023/A:1026563109217, 2000.

Lohbeck, K. T., Riebesell, U., and Reusch, T. B. H.: Adaptive evolution of a key phytoplankton species to ocean acidification, Nat. Geosci., 5, 346-351, doi:10.1038/ngeo1441, 2012.

Melzner, F., Thomsen, J., Koeve, W., Oschlies, A., Gutowska, M. a., Bange, H. W., Hansen, H. P., and Körtzinger, A.: Future ocean acidification will be amplified by hypoxia in coastal habitats, Mar. Biol., 160, 1875-1888, doi:10.1007/s00227-012-1954$1,2013$.

Menden-Deuer, S. and Lessard, E. J.: Carbon to volume relationships for dinoflagellates, diatoms, and other protist plankton, Limnol. Oceanogr., 45, 569-579, doi:10.4319/lo.2000.45.3.0569, 2000.

Nielsen, L. T., Jakobsen, H. H., and Hansen, P. J.: High resilience of two coastal plankton communities to twenty-first century seawater acidification: Evidence from microcosm studies, Mar. Biol. Res., 6, 542-555, doi:10.1080/17451000903476941, 2010.

Omstedt, A., Gustafsson, E., and Wesslander, K.: Modelling the uptake and release of carbon dioxide in the Baltic Sea surface water, Cont. Shelf Res., 29, 870-885, doi:10.1016/j.csr.2009.01.006, 2009.

Paul, A. J., Bach, L. T., Schulz, K.-G., Boxhammer, T., Czerny, J., Achterberg, E. P., Hellemann, D., Trense, Y., Nausch, M., Sswat, M., and Riebesell, U.: Effect of elevated $\mathrm{CO}_{2}$ on organic matter pools and fluxes in a summer Baltic Sea plankton community, Biogeosciences, 12, 6181-6203, doi:10.5194/bg-12-6181-2015, 2015.

R Development Core Team: R: A language and environment for statistical computing, Vienna, Available AT: http://www.r-project. org/ (last access: 10 September), 2013.
Reusch, T. B. H. and Boyd, P. W.: Experimental evolution meets marine phytoplankton, Evolution, 67, 1849-59, doi:10.1111/evo.12035, 2013.

Riebesell, U.: Effects of $\mathrm{CO}_{2}$ enrichment on marine phytoplankton, J. Oceanogr., 60, 719-729, doi:10.1007/s10872-004-5764-z, 2004.

Riebesell, U., Czerny, J., von Bröckel, K., Boxhammer, T., Büdenbender, J., Deckelnick, M., Fischer, M., Hoffmann, D., Krug, S. A., Lentz, U., Ludwig, A., Muche, R., and Schulz, K. G.: Technical Note: A mobile sea-going mesocosm system - new opportunities for ocean change research, Biogeosciences, 10, 18351847, doi:10.5194/bg-10-1835-2013, 2013.

Rossoll, D., Bermúdez, R., Hauss, H., Schulz, K. G., Riebesell, U., Sommer, U., and Winder, M.: Ocean acidification-induced food quality deterioration constrains trophic transfer, PLoS One, 7, e34737, doi:10.1371/journal.pone.0034737, 2012.

Rossoll, D., Sommer, U., and Winder, M.: Community interactions dampen acidification effects in a coastal plankton system, Mar. Ecol.-Prog. Ser., 486, 37-46, doi:10.3354/meps10352, 2013.

Sargent, J. R., McEvoy, L. A., and Bell, J. G.: Requirements, presentation and sources of polyunsaturated fatty acids in marine fish larval feeds, Aquaculture, 155, 117-127, doi:10.1016/S00448486(97)00122-1, 1997.

Sato, N., Tsuzuki, M., and Kawaguchi, A.: Glycerolipid synthesis in Chlorella kessleri $11 \mathrm{~h}$ II, Effect of the $\mathrm{CO}_{2}$ concentration during growth, Biochim. Biophys. Ac., 1633, 35-42, doi:10.1016/S1388-1981(03)00070-2, 2003.

Savchuk, O. P.: Resolving the Baltic Sea into seven subbasins: $\mathrm{N}$ and $\mathrm{P}$ budgets for 1991-1999, J. Mar. Syst., 56, 1-15, doi:10.1016/j.jmarsys.2004.08.005, 2005.

Schulz, K. G., Bellerby, R. G. J., Brussaard, C. P. D., Büdenbender, J., Czerny, J., Engel, A., Fischer, M., Koch-Klavsen, S., Krug, S. A., Lischka, S., Ludwig, A., Meyerhöfer, M., Nondal, G., Silyakova, A., Stuhr, A., and Riebesell, U.: Temporal biomass dynamics of an Arctic plankton bloom in response to increasing levels of atmospheric carbon dioxide, Biogeosciences, 10, 161180, doi:10.5194/bg-10-161-2013, 2013.

Thomsen, J., Gutowska, M. A., Saphörster, J., Heinemann, A., Trübenbach, K., Fietzke, J., Hiebenthal, C., Eisenhauer, A., Körtzinger, A., Wahl, M., and Melzner, F.: Calcifying invertebrates succeed in a naturally $\mathrm{CO}_{2}$-rich coastal habitat but are threatened by high levels of future acidification, Biogeosciences, 7, 3879-3891, doi:10.5194/bg-7-3879-2010, 2010.

Tomas, C. (Ed.): Identifying Marine Phytoplankton, Academic Press, San Diego, USA, doi:10.1016/B978-0-12-6930184/50011-2, 858 pp., 1997.

Torstensson, A., Hedblom, M., Andersson, J., Andersson, M. X., and Wulff, A.: Synergism between elevated $p \mathrm{CO}_{2}$ and temperature on the Antarctic sea ice diatom Nitzschia lecointei, Biogeosciences, 10, 6391-6401, doi:10.5194/bg-10-6391-2013, 2013.

Tsuzuki, M., Ohnuma, E., Sato, N., Takaku, T., and Kawaguchi, a: Effects of $\mathrm{CO}_{2}$ concentration during growth on fatty acid composition in microalgae, Plant Physiol., 93, 851-6, doi:10.1104/pp.93.3.851, 1990 . 
Utermöhl, H.: Zur Vervollkommnung der quantitativen Phytoplankton-Methodik, Series: Mitteilungen der Internationale Vereinigung für Theoretische und Angewandte Limnologie, E. Schweizerbart'sche Verlagsbuchhandlung, Stuttgart, Germany, 9, 1-38, 1958.
Yang, Y. and Gao, K.: Effects of $\mathrm{CO}_{2}$ concentrations on the freshwater microalgae, Chlamydomonas reinhardtii, Chlorella pyrenoidosa and Scenedesmus obliquus (Chlorophyta), J. Appl. Phycol., 279, 1-11, doi:10.1023/A:1026021021774, 2003. 